\title{
Sailing towards Crete: The Port of Modon
}

\author{
Farther on, we had very high mountains to the left and the Great Sea \\ to the right, as we passed through spacious places to Navarino and \\ as far as Methone, a city of the Venetians. ${ }^{1}$
}

After sailing through the Ionian Islands, pilgrims' galleys arrived at Modon, one of Venice's oculi capitales and one of the most important trading centres of the Ionian Sea (Fig. 46). Before entering the port of Modon, galleys would often stop at Sapienza, the biggest of a group of small islands located south of the town, protecting it from the open sea (Fig. 47). In the 14th century the Venetians established a lookout post on this island, from which flag or fire signals informed the city of approaching ships. ${ }^{2}$ Many pilgrims mention stopping at Sapienza and remaining there for hours or days when opposing winds prevented them from entering the port. ${ }^{3}$ Some of them refer to a church on a hill, as well as to hermits living on the island. The French Nompar de Caumont (1418) was the first to refer to the deserted island where hermits resided at a church dedicated to the Virgin. ${ }^{4}$ In 1470 the German nobleman Gaudenz von

1 English anonymous (1344-1345), in Hoade 1970, 56.

2 Hodgetts 1974, 41. The importance of the island of Sapienza for the safety of Modon's port was not overlooked by auspicious conquerors of the town. In 1529 Antonio Bosio, one of the commanders of the Hospitaller Knights, who a year later would attempt to occupy the town, had planned the building of another castle on the small island and its connection with the town by a pier. Foutakis $2017,117$.

3 In 1422 Felice Brancacci writes: 'A di 10, innazi giorno, ci partimo da Modone, e col nome di Dio seguimo nostro viaggio, e circa a terza avemo vento contrario, e tornamo indietro a Modone; e non potendo entrare in porto, tornamo a Sapienza, e quivi stemo tutto di e tutta notte.' Catellacci $1881,185$.

4 ' [...] une petite ylle déserte où il ne abite riens fors que hermitens que demeurent près de le mer au pié de le montaigne, en une églize que l'on appelle Sainte Marie de Sapience'. La Grange $1858,88$. 


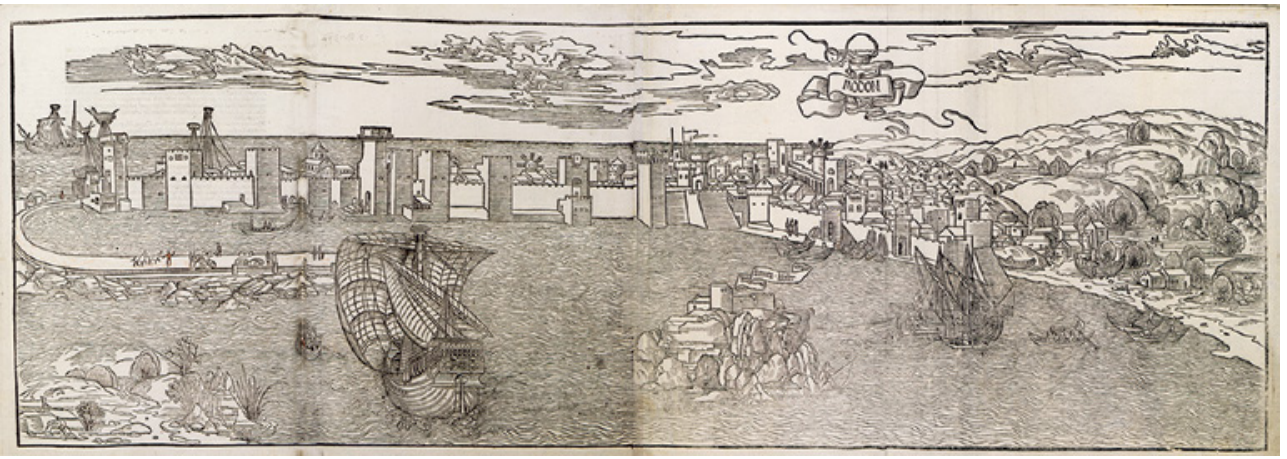

FIGURE 46 View of Modon, 1486, woodcut



FIGURE 47 Map indicating the location of the island of Sapienza and the port of Modon

Kirchberg also mentions the church, but not the hermits. ${ }^{5}$ The final reference to the church of the Virgin at Sapienza within the time frame of this study is in 1532 by Denis Possot. ${ }^{6}$ The ruins of a church on the island remain to this day. Its date of construction and its dedication have not been determined with

5 'Item nöben Madon über ligt ain intzl genanndt Sapienncia. Darauf ligt ain closter.' Röhricht $1905,111$.

6 'Du costé du nord et au devant, il y a une plage et une eglise.' Schefer 189o, 282. 
certainty, but it is believed to have been built during the ecclesiastical building activity of the 11th or 12th century. ${ }^{7}$

The Florentine pilgrim Lionardo Frescobaldi, who visited Modon in September 1384, describes the island of Sapienza most eloquently. ${ }^{8}$ In his description he includes all of the information provided by other pilgrims about the small safe harbour of the uninhabited island, the lookout post and the hermits residing in the church, attesting to what is also known from archaeological and archival evidence. What differentiates his narration is the fact that he places the as yet unidentified church of St Leo, Modon's most venerated saint, on Sapienza. Although the location of St Leo's church has not been determined, according to all the evidence it should have been situated close to the town of Modon, most probably near the sea, where the saint's body was found. Frescobaldi's fellow traveller, Simone Sigoli, places this church halfway up a hill, outside the town. ${ }^{9}$

The town's port was usually the pilgrims' first stop in the Peloponnese and provided a safe harbour; it had the capacity to supply ships and travellers, as well as markets in both the town and the borgo, where traders and crew could carry out their commercial transactions. ${ }^{10}$ The Italian traveller Gabriele Capodilista (1458) eloquently expresses the way Modon was perceived at the time: the most famous town of the Peloponnese (the 'Morea'), where all the ships travelling to Venice docked. ${ }^{11}$

$7 \quad$ Anagnostakis 201ob, 116.

8 'Dirimpetto al porto di Modona si è un grandissimo poggio, il quale si chiama il Poggio della Sapienza; nel qual poggio anticamente solevano andare i filosofi e i poeti a fare loro arti. E in questo grandissimo monte, alla sommità di esso, si è una certa torre imbertescata di legname in su che stanno certe guardie; e come veggono apparire vele per mare, fanno cenni con certi panni lini bianchi in su mazze, secondo da che parte vengono, avendo dati i segni quanto è di mestieri a difesa e offesa, per modo che 'l porto, che è tra questi due monti, cioè tra quello di Modona e quello della Sapienza, è sicurissimo così da' corsali come da' venti. Ha nel Poggio della Sapienza molti eremiti a fare penitenza de' lor peccati. Quasi a mezzo la costa del poggio si è la chiesa dov'è il corpo di santo Leo; e in quello paese sono molti pedoti, cioè conoscitori dove sono gli scogli del mare coperti dalle acque.' Lanza 1990a, 174.

9 '[...] a capo a questo Modone in su d'una montagna a mezza piaggia [...]'. Lanza $199 \mathrm{ob}, 220$.

$10 \quad$ Hodgetts 1974, 368-368; Gertwagen 200, 147.

11 'Questa cità di Modone è de le più famose cità de la Morea, dove sempre capitano tuti i navilij che veneno de Levante per andar a Vinezia, et è situata in piano nel litto del mare, sotoposta a la prefata illustrissima Signoria.' Momigliano Lepschy 1966, 174. 


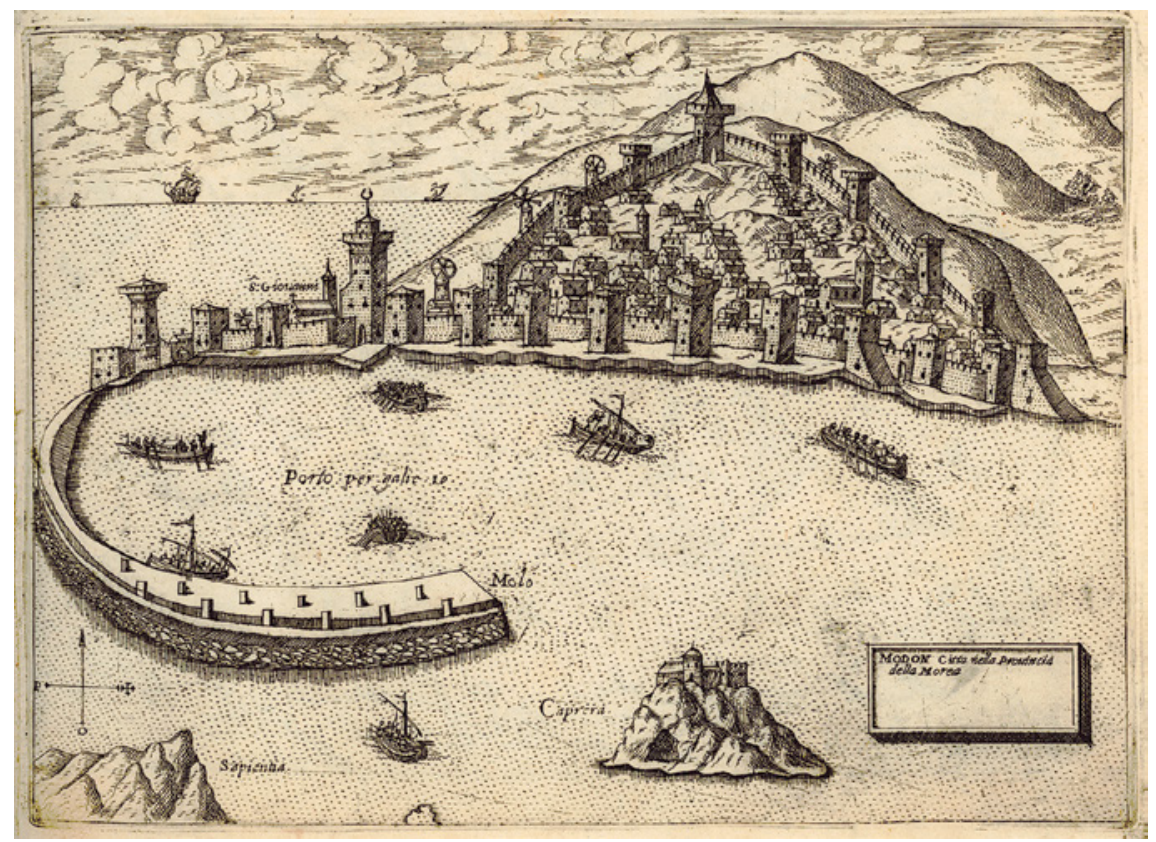

FIGURE 48 View of Modon, $c .1574$, engraving

The first impression of the strongly fortified small town seems to be common for most of the pilgrims, who almost never omit to emphasise the safety of the harbour, so important for sea travellers (Fig. 48). ${ }^{12}$ The Spanish voyager Pero Tafur, who visited Modon in 1436, provides one of its most concise descriptions, referring not only to the capacity of the port to provide safe harbour and supplies for the galleys, but also to its commercial importance. He also gives detailed information about the town, its inhabitants and its products. ${ }^{13}$

When disembarking at Modon, as in the case of Corfu, pilgrims were completely aware that they were visiting a town in the former territory of

12 Roberto da Sanseverino (1458-1459) writes: 'Et parsegli molto bene esser vero quello che avevano inteso del dicto Modone, cioè ch'el havesse lo mazore et megliore porto et sorzedore cha locho fusse in Levante, perché tra la dicta terra et lo soprascripto schoglio, nominato Sapientia, è dicto porto et sorzodore, ove stariano sechurissime quante nave, galee et altri naviglij sono suso quello mare.' Cavaglià and Rossebastiano 1999, 239.

13 'Este mesmo día llegamos al puerto de Modón, que es entre la dicha villa e la isla Sapiencia, e allí surgimos, e decendimos en tierra por algunos refrescamientos para el navío, e aun por algunos negoçios que el patrón e algunos de la galea tenían en el lugar, por cuanto ellos eran venecianos, e el lugar del señorío suyo. Este es lugar de dos mill vecinos, la mar lo cerca de dos partes, bien murado e asaz fuerte, aunque llano, muchas huertas de todas frutas e tierra muy abastada a modo del Andalucía; buenas posadas; la lengua griega, el regimiento de Veneza.' Pérez Priego 2006, 241. 
Byzantium. Their references concerning the local community attest to the fact that Modon remained, in respect of its population and prevailing culture, a Greek city. ${ }^{14}$ Another interesting piece of information conveyed in most of the travelogues, probably related to the relief of reaching the middle of a difficult and dangerous journey, is the fact that Modon was located halfway between Venice and Jerusalem. ${ }^{15}$

The medieval town of Modon was a multicultural city with a mixed population of Greeks and Latins who resided in the walled castro, as well as Albanians, Jews and Gypsies living in the borgo (Fig. 49). It was not uncommon for travellers to meet fellow countrymen in Modon who often offered them accommodation during their stay, as in the case of the Flemish Joos van Ghistele. ${ }^{16}$ In the town's port one could find travellers from all over the world, while in the borgo pilgrims were intrigued by their acquaintance with Gypsies. ${ }^{17}$ Nevertheless, what stands out more in the pilgrims' descriptions is the city's strong fortification and the constant Ottoman threat.

As far as the actual town is concerned, pilgrims described it as small in size, with wide streets and wooden houses built very close to one another. ${ }^{18}$ As a major commercial port, Modon offered facilities to travellers, traders and crew of the various ships frequenting it. Pilgrims were accommodated at the mendicant monasteries of the town, while German travellers usually resided at the 'House of the Teutonic Lords' (domun dominorum teutonicorum, Teutschen Herrn Hauß, tutsches orden $\beta$ ), most probably a house run by the Order of

14 Wilhelm Tzewers (1477-1478): ‘[...] Greci sunt [...]'. Wiesbaden 2004, 48; in 1480 the anonymous author of Le voyage de la saincte cyté de Hiérusalem writes: 'Tous ceulx de la ville sont Grecz [...] Les escoles et eglises sont quasi toutes grecques [...].' Schefer 1882, 46; the German pilgrim Bernhard von Breydenbach, who visited Modon in 1483, reports: 'Do selbet ist kriechsche sprach in gebruch vnd synt die menschen gemeynlichen synt Pauls glauben habent genant die cristen vom gurtel.' Mozer 2010, 94; in 1492-1493 Peter Fassbender writes: '[...] und die stat stoestz sych an Griecken und dae beghynt Grieckssche spraich'. Röhricht and Meisner 188oc, 251.

15 Stephan III of Gumpenberg (1419): '[...] ligt auff halben Weg von Venedig und dem heyligen Land'. Feyerabend 1584b, 237v.

16 'Dus daer commen zijnde, zo logierden de voorseyde up maerct ten house van eenen barbier, gheboren van Biervliet, daer ghehuwet an eene vrauwe van dien lande [...]'. Gaspar 1998,357 .

17 French anonymous (1480): '[...] il y en a de toutes nations de gens qui parlent chascun divers langaiges'. Schefer 1882, 46. Pierre Barbatre, who visited Modon in 1480, mentions that: '[...] arriverent IIII grosses naves de Venize, lesquelles sont envoyés en Cypre pour certaines causes. En icelles naves sont gens de plusieurs nacions entre lesquieulx je en ay trouvé de Paris, de Tournay, de Bourges, de Lyon et aultres lieulx ausquieulx j'ay enquis des nouvelles.' Pinzuti and Tucoo-Chala 1972-1973, 164.

18 Pietro Casola (1494): 'Io non li sapi vedere caxe ne palazi degni de descriptione; per quella che ella è, è spessa de caxe.' Paoletti 2001, 144. 


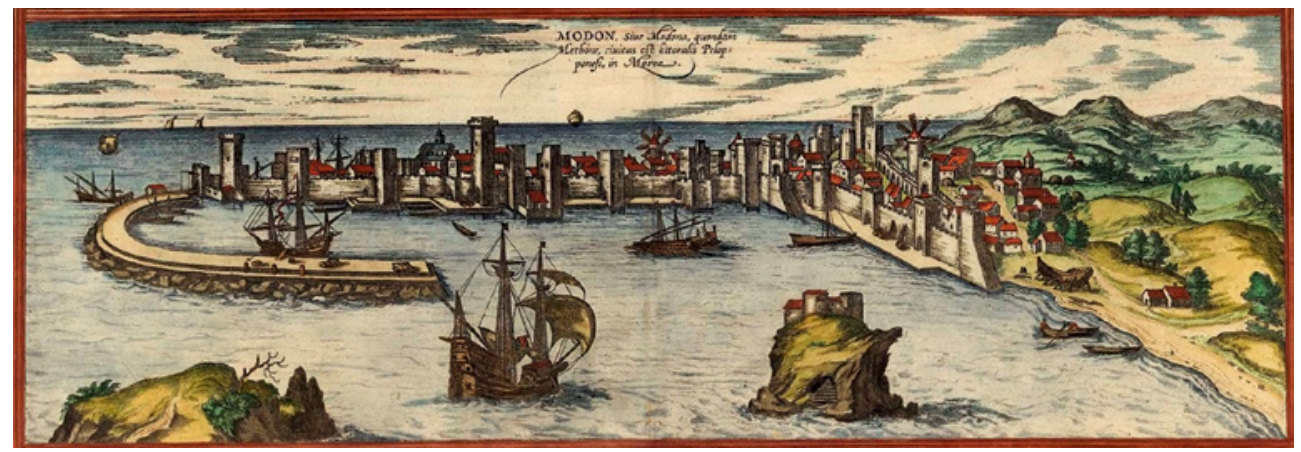

FIGURE 49 The town of Modon, late 15th century, engraving

Brothers of the German House of St Mary in Jerusalem or, according to other scholars, an establishment such as the Fondaco dei Tedeschi in Venice. ${ }^{19}$ The general impression of the town was quite positive for most of the pilgrims, but, as the 15th century drew to an end, the effect of the Ottoman attacks had become apparent. As a result of the constant Ottoman threat, the town had diminished in population and was, according to Pietro Casola, 'very badly kept in every way'. ${ }^{20}$ The depictions of Modon in the isolarii of the period, as well as in some pilgrims' narratives, as abstract as they may be, provide a quite accurate idea of the port and the town, with its impressive fortifications, windmills and the cathedral being visible from the ship.

Because of the limited space within the castro, a large number of houses, warehouses, commercial stores and, of course, churches and monasteries were built in the borgo, and almost all of the pilgrims visited them. The Flemish trader Jean de Tournai visited Modon in 1488 and informs future travellers about the town's markets and abundance of products offered at good prices, while the German Felix Fabri (1480, 1483-1484) eloquently conveys the contrast between the lively borgo and the walled town. ${ }^{21}$

19 Hassler 1843-1849, vol. 1, 18o; Feyerabend 1584a, 125r; Denke 2011, 39. The Order of Brothers of the German House of St Mary in Jerusalem, commonly the Teutonic Order (Deutscher Orden, Deutschherrenorden or Deutschritterorden), is a Catholic religious order founded $c .1190$ in Acre as a military order to aid Christians on their pilgrimages to the Holy Land and to establish hospitals. See Boas 2006, esp. 6. About the Teutonic Order in the Peloponnese, see Opshal 1994, esp. 55-67. The Fondaco dei Tedeschi, founded in the early 13th century, was a landing point for goods transported by German merchants who stored them there. German-speaking populations who had a dedication agreement with the Serenissima operated there for their trade. See Browning Lemann 2006; Denke 2011, 339, n. 450; Gertwagen 200ob, 147.

$20 \quad[\ldots]$ molto male in ordine de ogni cosa'. Paoletti 2001, 144.

21 Jean de Tournai (1488): 'La ville de Méthoni est une très forte ville, un très bon port, bon pays avec toutes sortes de vivres à bon marché. Et si vous n'avez pas fait provision de 
Due to the severe destruction that followed the second Ottoman occupation, the number of churches and monasteries, both Latin and Orthodox, existing in the town and the borgo of Modon cannot be determined. It could be safely assumed that there would have been a large number of churches dating from the time before the Venetian occupation, and some of them would have been seized by the town's new rulers, thus converted for use by the Latins. Nevertheless, only the cathedral, dedicated to St John, can be identified in the ruins of a building located at the north-east end of the castle. Aside from the cathedral, very little information exists in regard to the churches in Modon. Archival documents attest to the existence of two other Latin churches, St Anne and St Mark, as well as to two mendicant monasteries, the Dominican one in the castro and the Franciscan one outside the city walls. ${ }^{22}$ Also outside the town was the church of St Mary, characterised as de extra, ala splaza or valverde. The first two epithets indicate its location beyond the walls and near the sea, but the third one, according to Ann Christine Hodgetts, may suggest an attempt to establish a scuola as a daughter foundation of Santa Maria Valverde of Venice. ${ }^{23}$ In the $15^{\text {th }}$ century a commercial fair was held around the church on 8 September, the day of the Nativity of the Virgin, lasting for three days. ${ }^{24}$ Undoubtedly there would have been a number of Orthodox churches as well, in and around Modon. Their names and locations are unknown, but several travelogues refer to their existence. ${ }^{25}$

vivres jusque-là ce ne serait pas grand mal car vous en auriez à bien meilleur marché ici que nous n'avions eu à Venice.' Péricard-Méa and Blanchet-Broekaert 2012, 163. Felix Fabri (1480, 1483-1484): 'Ab extra est suburbium, et ad partem suburbii ad clivum montis sunt multae domunculae parvae et tuguriola stupa et calamis et sarmentis factae et luto compactae, et est quasi villula, inhabitantque illam Zigari illi, qui per orbem vagantur, de quibus supra Fol. 8o dictum est. Et omne forum equorum, porcorum, et quidquid tumultuosum est, agitur in illo loco extra urbem, et in urbe est quies et pax, et negotiationes quietae in ea tractantur.' Hassler 1843-1849, vol. 3, 338 .

The church of St Anne appears in a will of 1375 by which Menegetus Servidius of Modon ordered that the money of which he had defrauded the churches of St John and St Anne should be returned. This church might have been in the town or it could be identified as the church of St Anne located outside the town, the lands of which were ascribed to the bishop of Modon. The church of St Mark appears in a document of 1343, in which the castellans requested that building supplies for it should be sent without tax, indicating that it was under the protection of the government. Hodgetts 1974, 389 .

23 Hodgetts 1974, 379-380, 389.

24 Georgopoulou 2013, 136; Hodgetts 1974, 389.

25 Pierre Barbatre (1480): 'En la cité sont plusieurs eglises de Grecz [...].' Pinzuti and TucooChala 1972-1973, 121. Felix Fabri (1483) also states that: 'De ecclesiolis Graecorum, quae etiam ibi sunt, non curavimus.' Hassler 1843-1849, vol. 3, 334 . 
As for the encounter with an Orthodox population and its religious practices that appeared to intrigue the pilgrims on Corfu, this no longer seems to surprise them; having sailed through the Ionian Sea, by the time they arrived at Modon they were probably accustomed to them to a certain extent. Of course, they are still interested in this different reality: in $\mathbf{1 4 8 2}$ the Franciscan friar Paul Walther Guglingen mentions that several of his fellow travellers entered a Greek church 'out of curiosity' to witness the way in which the Orthodox mass is performed, while one can still find in the travelogues descriptions of the 'peculiar' attire and habits of the Greek priests. ${ }^{26}$

In any event, in the case of Modon references of this type are not frequent. Modon did not offer the rich variety of experiences pilgrims encountered on Corfu and would later encounter in Candia. The social and, to a certain extent, religious homogeneity that was achieved on Corfu and was expressed in a spectrum of rituals, both religious and secular, that attracted the attention of and impressed the travellers does not seem to apply in the case of Modon. Undoubtedly, as in all Venetian-ruled Greek territories, the Latins and the Orthodox participated in common political and ecclesiastical ceremonies, but it seems that they were held less often, and, when they occurred, they were less complicated and less elaborate than on Corfu. In addition, and unlike the town of Corfu, Modon had what seems to have been a quite important relic - the body of a pilgrim saint, St Leo - thus providing a strong cultic focus that could potentially overshadow other 'religious attractions'. Whatever the situation was, the vast majority of pilgrims' narratives do not provide any information concerning other churches, neither Latin nor Orthodox, besides the cathedral and the two monasteries of the Dominicans and the Franciscans.

In regard to the Orthodox churches mentioned by the pilgrims, none of them exist today. They were all located outside the city walls and were visited by few pilgrims, whose testimonies are thus valuable sources of information.

\subsection{The Church of St Nicholas}

The Orthodox church of St Nicholas is no longer extant. Its presence is attested only in written sources, while no archaeological remains have survived to indicate its location. It is mentioned in two travelogues dating to 1487 and 1494 and was identified by Ann Christine Hodgetts as St Nicolai Motonensis extra portum, which had been attested already from $1207 .{ }^{27}$ In that year the

26 'Ibidem intraverunt ecelesiam Grecorum quidam peregrini de nostris ex curiositate et audierunt eorum missam [...].' Sollweck 1892, 81.

27 Pilgrims Nicholas le Huen (1487) and Pietro Casola (1494). Huen 1488, n.p.; Paoletti 2001, 143. About its identification, see Hodgetts 1974, 391-392. 
pope had confirmed an annual grant made to the chaplain by William de Champlitte in memory of Henry Rondeth. ${ }^{28}$ It is quite possible that the Venetians allowed it to continue in the Greek rite, even more so since it was located outside the town, where the Greek bishop was compelled to reside. Pietro Casola (1494) states that the church was restored from the offerings of the mariners. ${ }^{29}$ Both pilgrims referring to the church of St Nicholas had visited it and mention making offerings to the saint, the traditional protector of sailors: 'And outside [the town] there is a charming and beautiful church of St Nicholas, where we offered to our great relief candles devoted to him to avoid the turbulent sea. ${ }^{30}$

\subsection{The Church of St George}

The church of St George was also destroyed, and all information about it derives from written sources. According to pilgrims' travelogues, it was located outside the town, near a well from which travellers got their water supplies. The first mention of this church was made in 1418 by the French pilgrim Nompar de Caumont, while in 148 o the anonymous author of Le voyage de la saincte cyté de Hiérusalem testifies that, 'In the town there is no fresh water, so we had to refill our barrels near St George outside the town.'31 It has been supported that St Leo's relic could possibly have been kept in the church of St George before ending up permanently in the town's cathedral. ${ }^{32}$

\subsection{The Church of St Leo}

The church of St Leo, Modon's most famous and revered saint, is mentioned by three pilgrims in 1384 and 1418 . There has been much discussion concerning the building's actual location, and in the early 196os a ruined monumental structure, situated $3 \mathrm{~km}$ north-east of the castle of Modon, was identified as the church of St Leo (Fig. 50). ${ }^{33}$ This building is today in ruins and covered by dense vegetation, while only its south and west surrounding walls are still

28 Bon 1969, 92; Hodgetts 1974, 392; Kappas 2010, 197.

29 '[...] si fa de novo de elemosine de marinari.' Paoletti 2001, 143.

3o Nicholas le Huen (1487): 'Et au dehors a une chappelle gracieuse \& belle de sainct Nicholas: ou portasmes par grant soulas des cierges: deuotes a luy pour eviter lennuy de la mer passee.' Huen 1488, n.p.

31 Nompar de Caumont (1418): 'Et retournay par ung autre chemin, où il ha ung lotgis ouvert que s'apelle Saint George de les Tribulleye, ou il ha une chapelle de monseigneur Saint George que les Grexs tiennent [...].' La Grange 1858, 91. French anonymous (1480): 'En la ville, il n'y a point d'eaue doulce que de pluye et nous faillut envoyer remplir nostre baril au puys sainct Georges qui est en une lieue dehors de la ville et cousta deux marquetz.' Schefer 1882, 47 .

$32 \quad$ Follieri 1971, 390-392; Steiris 2009-2010, 419.

33 Demodos 1958, 140-141; Pallas 1963, 104-105; Pallas 1971, 87-94; Steiris 20o9-2010, 420. 


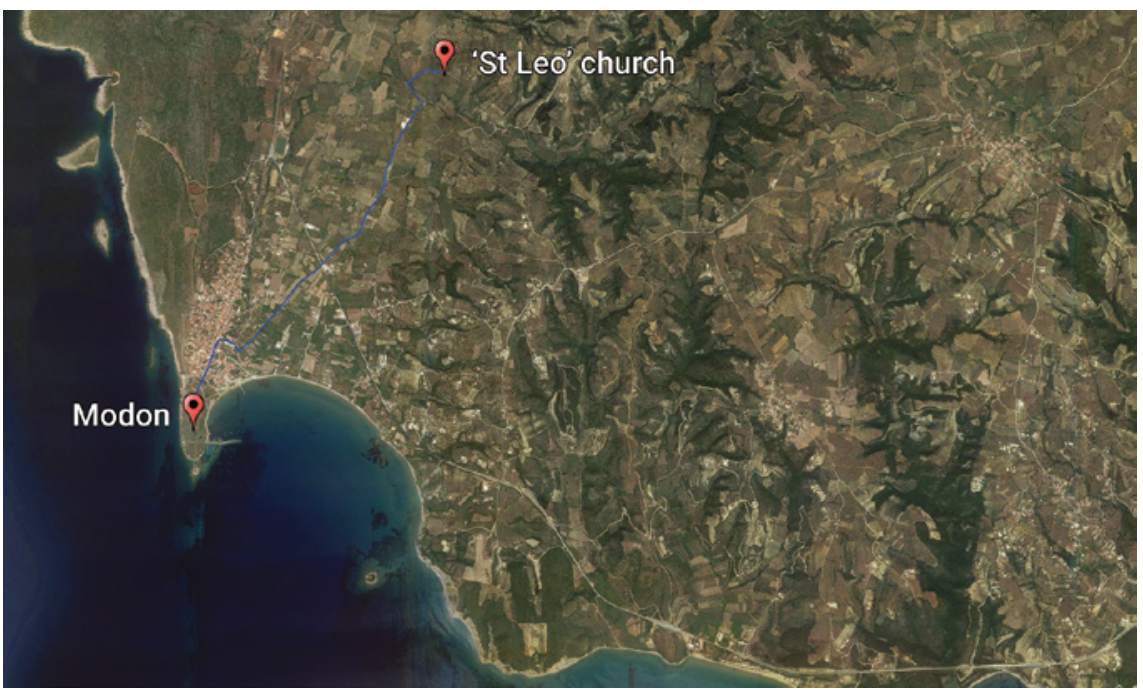

FIGURE 50 Map indicating the location of Agioleos, north-east of Modon

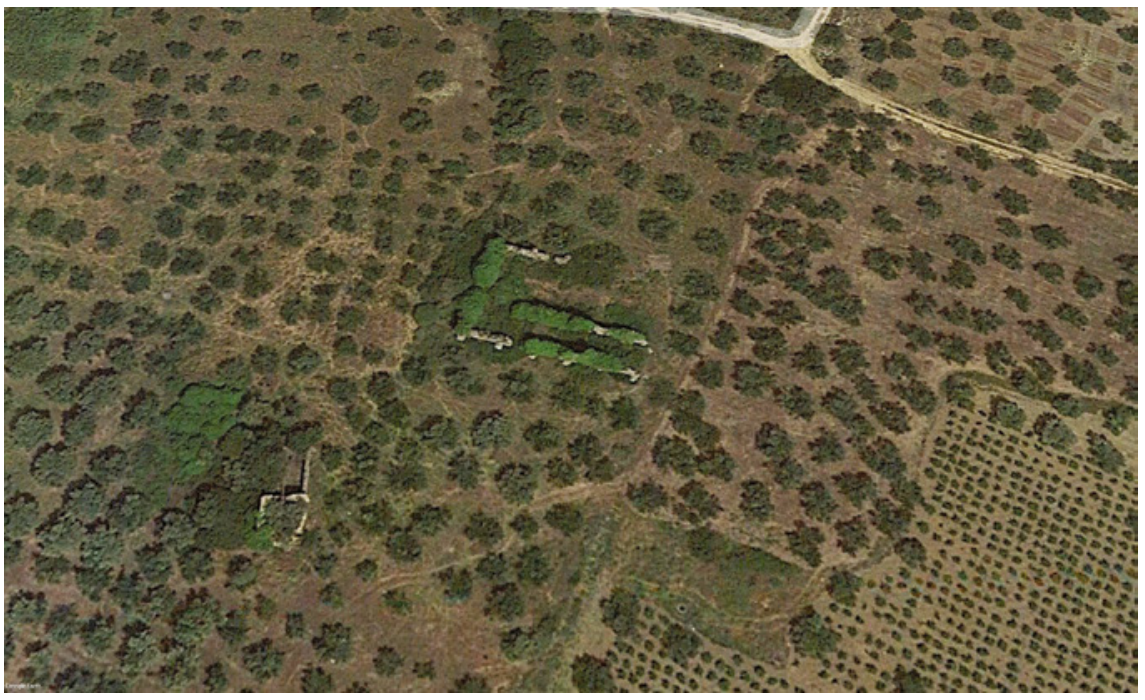

FIGURE 51 The building of Agioleos in its present state

preserved and visible (Fig. 51). It has never been thoroughly studied, although it was cleared and partly excavated in 1969 by Dimitrios Pallas. ${ }^{34}$ The identification of this building with the church of St Leo was mainly based on its local toponym, Agioleos (St Leo). It is worth mentioning that this toponym appears

Pallas 1971, 87-94; Michaud 1970, 996, 1000. 


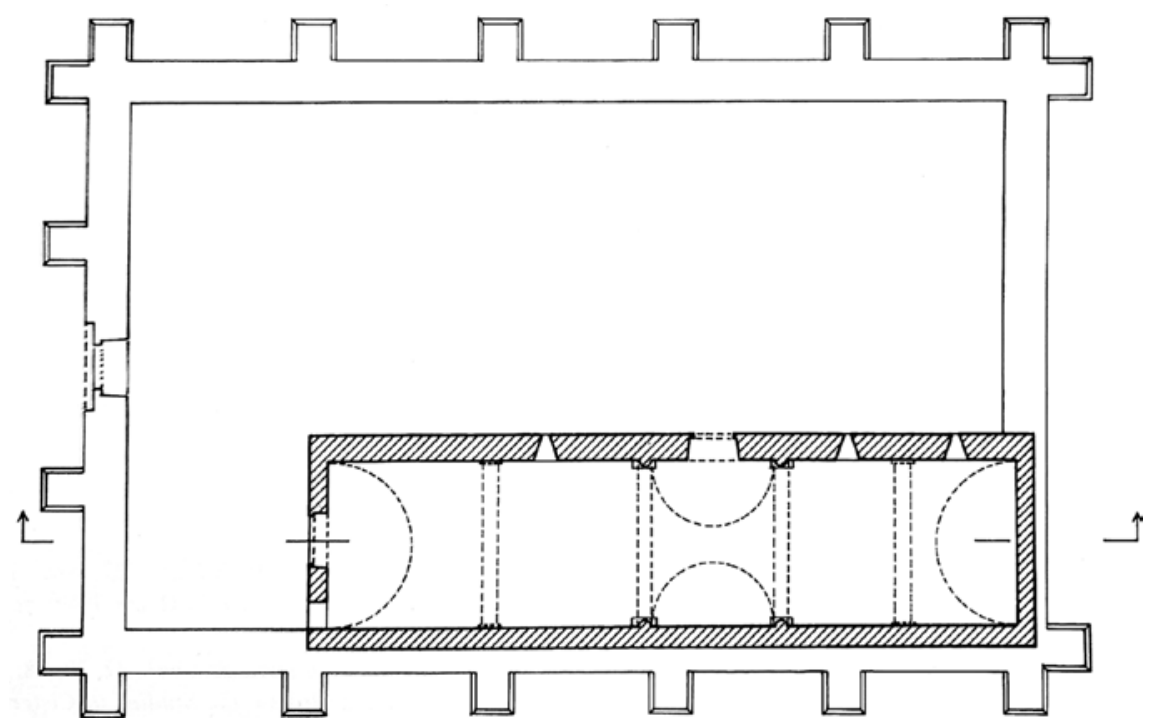

FIGURE 52 Plan of the church of 'St Leo', Modon, 15th century

for the first time in the 1930s, while the travelogues of the 19th century refer to the building simply as a church in the area of Palio Methoni. ${ }^{35}$

The first excavator of the site, Dimitrios Pallas, characterised the building as a cross-shaped church belonging to the Latin doctrine, enclosed by a monumental compound and combining both Gothic and local Greek architectural features (Fig. $5^{2}$ ). He dated the whole construction to the late $15^{\text {th }}$ century. ${ }^{36}$ Twenty years later, Charalambos Bouras re-examined the site, conducting yet another partial excavation. ${ }^{37}$ Bouras's findings were much different than those of Pallas. He saw at least two construction phases: an underlying large three-aisled church, typical of Frankish architecture, with elements of the French Gothic style of the first half of the 13th century, and a late 15th-century one-aisled, crossed-shaped church (Fig. 53) $\cdot^{38}$ Going further, Bouras identified the 13th-century building with the Cistercian monastery of Santa Maria de Verge of Modon, which was known to exist outside the city walls. ${ }^{39}$ As far as

35 Valmin 1930, 153; Bouras 1989, 302; Gell 1823, 49; Aldenhoven 1841, 164.

36 Pallas 1971, 87-94.

37 Bouras 1989, 302-322.

38 Georgios Papathanasopoulos also dated the building to the 13th century. Papathanasopoulos 1965, 94; Bouras 1989, 303-315, esp. 307 .

39 This identification was based both on architectural and constructional elements, as well as on written evidence. The simple and austere construction, the absence of a transept, 


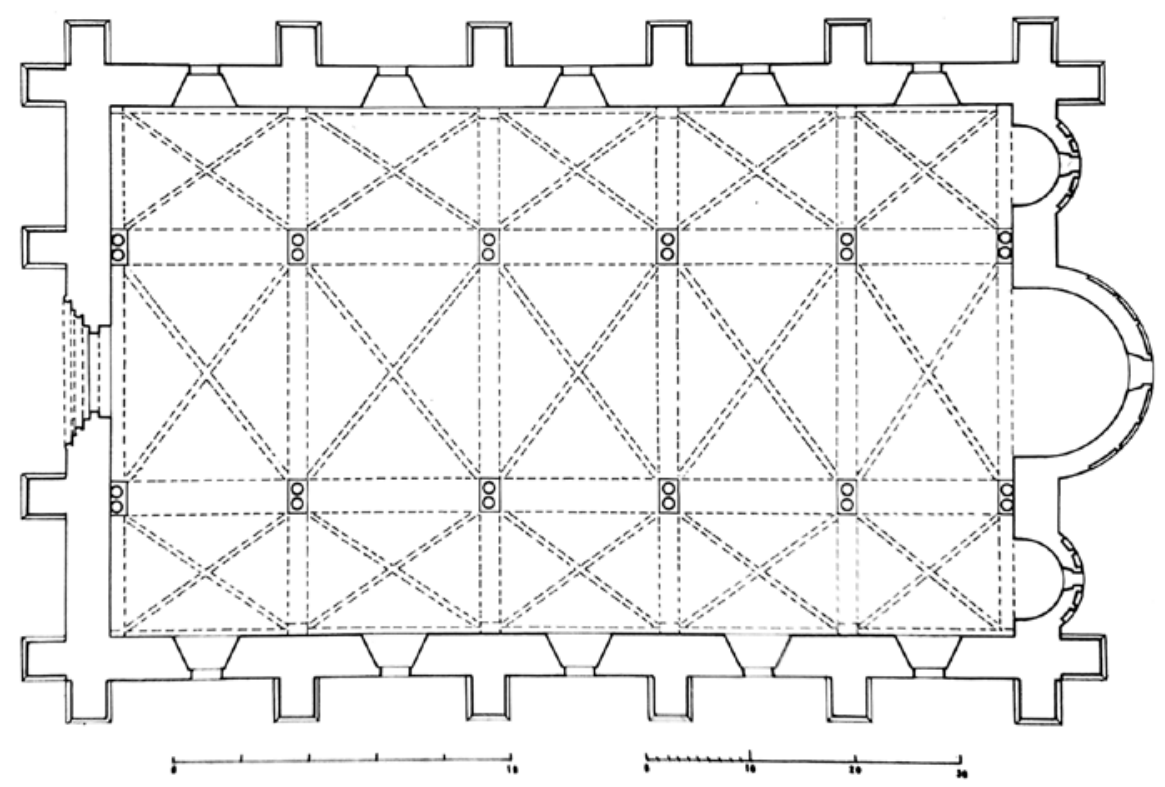

FIGURE 53 Plan of the church of 'St Leo', Modon, during the monument's first phase, 13 th century

the 15th-century building is concerned, unlike Pallas, Bouras disagreed with its attribution to St Leo's church. ${ }^{40}$ Based on travelogue references, as well as the saint's vitae, the church of St Leo was erected over his tomb, where his body was found, that is, on a shore near the city of Modon.

semi-columns or pilasters on the walls of the lateral aisles and the similarity of this church to the katholikon of the monastery of Zarakas in Stymphalia led Charalambos Bouras to assume that the building belonged to the then powerful Cistercian Order. Two papal epistles, one of Pope Clement IV in 1267 and one of Pope Gregory X in 1271, refer to a group of nuns of the Cistercian Order, who arrived in 1267 in Brindisi asking for protection after having been violently dislodged by the Greeks, who destroyed their convent in Modon. There are also mentions of two abbesses, Demeta Palaiologina and Isabella. After the destruction of their convent in Modon, the nuns settled in the area of Conversano in Italy. It is known that after the reoccupation of Constantinople by the Greeks in 1261 and the surrender of Monemvasia, Mystras and the Mani to the Byzantines in 1262, Greeks in the Peloponnese became particularly violent, destroying Latin monasteries located outside cities walls. These facts explain perfectly the brief history of the convent, while a big earthquake in 1303 completed its destruction. Bouras 1989, 311, 319-320; Brown 1958, 94; Orlandos 1955, 17; Unghelli 1721, 706-709; Zakythinos 1932, 32, 85; Miller 1908, 113-114.

Bouras 1989, 315-319. 
Only four pilgrims mention seeing St Leo's relic in the church dedicated to his name instead of the town's cathedral. Lionardo Frescobaldi, who visited Modon in 1384, places St Leo's church 'halfway up a hill', but on the islet of Sapienza, while his fellow traveller Simone Sigoli places it 'outside Modon, halfway up a hill near the shore.41 The most detailed report concerning the church is given by Nompar de Caumont, who travelled to the Holy Land in 1418. He places the church 'a mile and a half outside the city of Modon, near the sea', while he also dates its erection: 8 o years before his visit, that is, in 1338, adding that it was Greek Orthodox..$^{42}$ The fourth traveller mentioning St Leo's church, the German nobleman Arnold von Harff (1497), places it inside the city walls and characterises it as a Mutterkirche ${ }^{43}$ At the date of von Harff's travels, in the late 15th century, all the other surviving sources place St Leo's relic in the cathedral of St John. Most probably the German pilgrim misunderstood the dedication of the church, possibly due to the fame of the relic held in it. At this

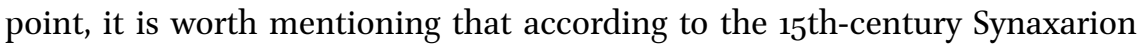
containing St Leo's vita, the saint's body was buried at the seashore of an area near Modon called 'P $\hat{\omega} \sigma o \nu \chi \hat{\omega} \mu \alpha^{44}$ So, assuming that there is a hint of truth to the legend and St Leo's church was erected above his tomb, it should have been near the sea.

Concluding, two of the travelogues (Frescobaldi's and Nompar de Caumont's), as well as the Synaxarion of St Leo, place the saint's church near the sea. In addition, Nompar de Caumont gives a date of the erection of the building, 1338, which does not correspond to the Palio Methoni church that is quite safely dated to the 13th century. Simone Sigoli's description does not allow an identification of the place where the church was, while von Harff's mention that the church was a Mutterkirche inside the city walls, in a period when all the other travelogues place the relic in the town's cathedral, is most probably a misunderstanding. In any case, neither the descriptions provided in the travelogues, nor the archaeological evidence allows a safe identification of the church in Palio Methoni with St Leo's church (Fig. 54). ${ }^{45}$

41 Lionardo Frescobaldi (1384), see n. 8 above. Simone Sigoli (1384): 'A capo a questo Modone in su d'una montagna a mezza piaggia ha una chiesa, nella quale è il corpo di santo Leo.' Lanza 199ob, 220.

42 La Grange 1858, 9o. See $n .71$ below.

43 Brall-Tuchel and Reichert 2007, 98.

44 Enrica Follieri identified 'P $\hat{\omega} \sigma o \nu \chi \hat{\omega} \mu \alpha$ ' with an area between Modon and Coron called

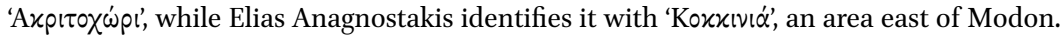
Follieri 1971, 407; Anagnostakis 2010b, 142.

Bouras 1989, 315-319; Kappas 2010, 241. 




FIGURE 54 Remains of the church of 'St Leo', Modon

What can be quite safely assumed is that at some point between 1418 and 1469 St Leo's relic was moved and then kept permanently in the cathedral of Modon. Charalambos Bouras's explanation of the misunderstanding that led locals to name the church of Palio Methoni as St Leo is the assumption that the legend of the miraculous relic survived the Ottoman occupation of 1500 and the town's destruction and was in a much later period erroneously related to the ruined building outside the city. ${ }^{46}$ This explanation could be supported by pilgrims' narratives dated after 1500, which mention that, at this time, it was said that St Leo was still alive in the mountains around Modon. ${ }^{47}$ According to that, it seems quite improbable that Palio Methoni's church was the one erected in honour of St Leo, but there are still reservations, since the monument has not yet been fully excavated and studied.

$46 \quad$ Bouras 1989, 318.

47 Barthélemy de Salignac (1522): 'His locis audiui non sine admiratione agitari quaestionem de corpore sancti Leonis, aliquibus asterentibus, corpus dicti sancti in illa ciuitate requiescere, aliis vero contradictentibus, ipsum sanctum adhuc viuere, \& in vicinis monticulis latitare.' Kirchner 1593, n.p. Two other pilgrims, Denis Possot and Charles Philippe, who travelled in 1532, also mention that: 'Aulcuns disent que le corps sainct Leon est en icelle cité, les aultres disent qu'il est encores vivant.' Schefer 189o, 126. 


\subsection{The Latin Cathedral of St John}

Regarding the Latin churches and monasteries of Modon, it is the town's cathedral that amasses the largest number of references in the travelogues. Apart from the cathedral of St John, pilgrims also refer to the Franciscan and Dominican monasteries. It is clear from their descriptions that none of these impressed or even pleased the eyes of the pilgrims, since they characterise the cathedral as a 'sad and badly kept building' and the Dominican monastery as 'being in a very bad state', while the Franciscan priory is described as so poor that the Conventual friar Paul Walther Guglingen refuses to officiate in it. ${ }^{48}$ So, just as in Corfu, pilgrims visiting Modon were not impressed by its churches and monasteries, and this does not come as a surprise: the town was under the constant threat of the Ottomans, and its buildings had suffered damage on several occasions. Additionally, pilgrims had already seen the magnificent churches of Venice, as well as the ones in the major cities on the Dalmatian coast, and certainly the religious buildings of a town such as Modon could not compare in terms of architecture, decoration and wealth to those.

The cathedral of St John is, as already mentioned, the one that amasses the largest number of references compared to any other church or monastery in the town of Modon (Fig. 55). Dedicated to St John the Theologian, the church was located at the north-east end of the castle of Modon, almost next to the breakwater. In most of the depictions of Modon of the period, the cathedral stands out above the city walls. The actual date of its construction is uncertain. It was presumably built on the debris of a pre-existing Byzantine church. ${ }^{49}$ In its present state, traces of its surrounding walls are still visible, but no excavation has been carried out yet.

Based on the few remaining architectural elements, as well as two drawings of the church made by members of the Expédition scientifique de Morée in 1828, archaeologists deduce that St John was a three-aisled basilica of large proportions with Gothic style features and large pointed arched windows. The walls were reinforced with closely placed buttresses, while it had pitched roofs covering the central and lateral aisles (Fig. 56). ${ }^{50}$

After the fall of Modon to the Ottomans in 1500, the cathedral was burnt and later on restored and converted into a mosque. A minaret was added at its south-west corner; its large rectangular base is built of limestone voussoirs

48 Pietro Casola (1494): '[...] triste, molto male in ordine de ogni cosa [...]'. Paoletti 2001, 144. Alessandro di Filippo Rinuccini (1474): '[...] assai impedito [...]'. Calamai 1993, 53. Paul Walther Guglingen (1481-1483), see n. 107 below.

49 Kappas 2010, 244.

$5^{\circ} \quad$ Blouet 1831, 12; Kappas 2010, 244. 


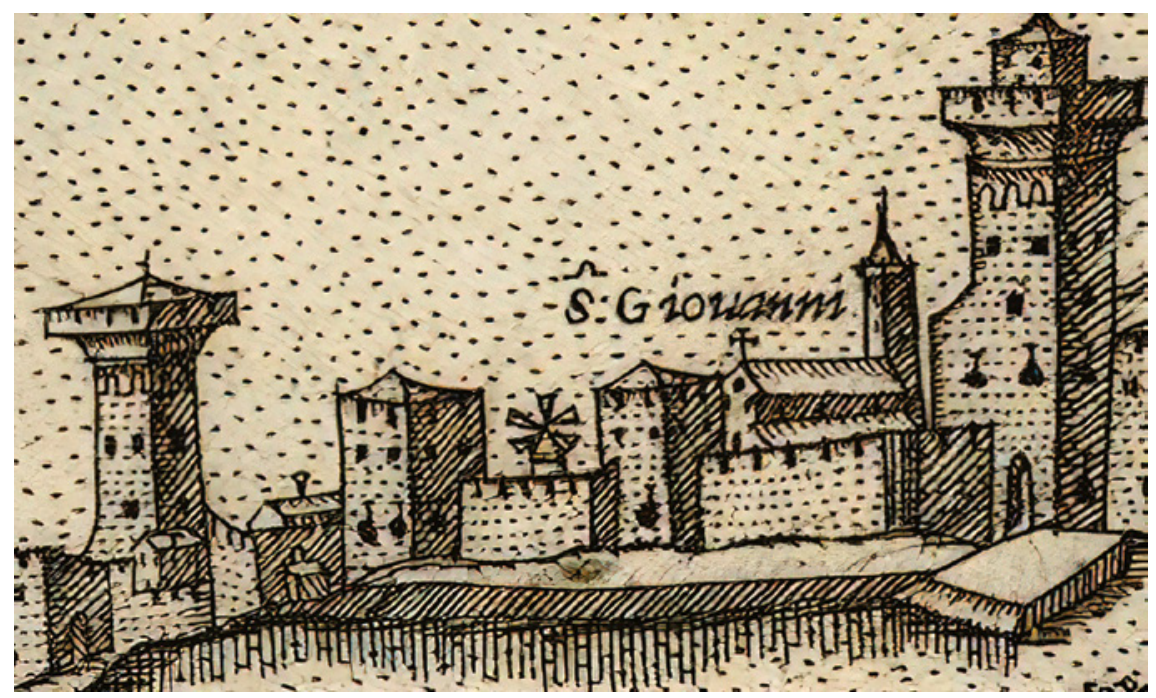

FIGURE 55 The cathedral of Modon, c. 1574, engraving. Detail of Fig. 48
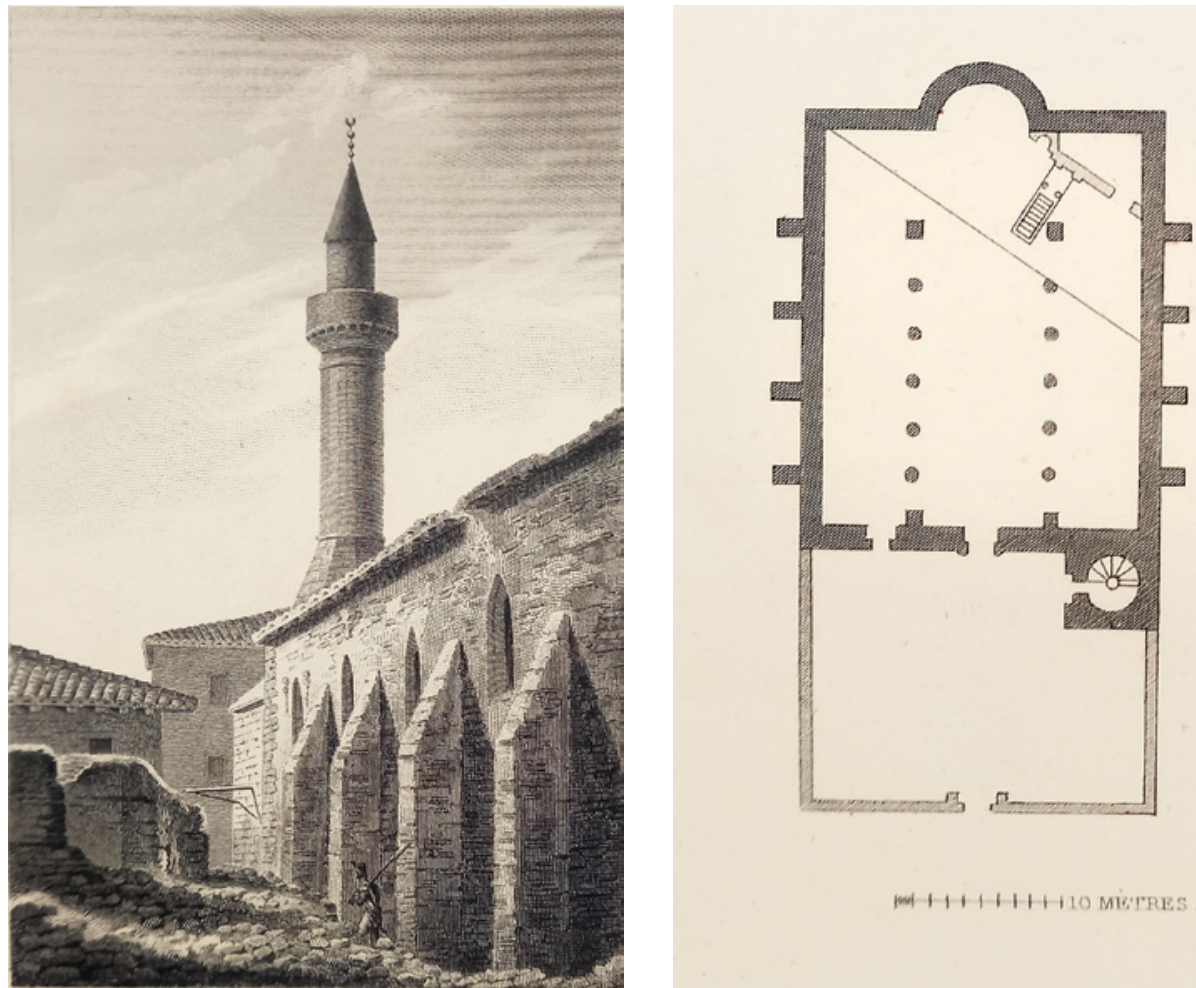

H H 1 H H 10 MiGrRes

FIGURE 56 Drawing and plan of the Latin Cathedral of St John, Modon, 19th century 
in second use, taken from the main building of the church of St John. ${ }^{51}$ Guillaume-Abel Blouet, a French architect who visited Modon in 1829, provided some further details about the building's architectural form and its interior, describing a large three-aisled basilica with marble columns and a minaret standing at one of its corners, indicating that it served as a mosque. ${ }^{52}$

Modon has been a diocese since the beginning of the 13th century. After its occupation by the Venetians in 1205, a Latin bishop was appointed to the town, with full jurisdiction over the property of the former Orthodox bishop. It must have been at this time that the Orthodox cathedral was seized by the Latins, along with the holy relic held in it at the time, the head of St Athanasius, Bishop of Modon..$^{53}$ The church as it was seen by medieval travellers was probably built in 1209 on the remains of the preceding cathedral, which was destroyed during the hostilities between the Venetians and the Franks two years earlier. ${ }^{54}$

The first official mention of the church of St John as a Latin cathedral dates back to 1438 , when the Orthodox delegation with the Patriarch of Constantinople Joseph II stopped at Modon on their way to the Council of Ferrara-Florence; 55 on 23 and 24 November respectively, the Latin and Orthodox bishops officiated at the cathedral of St John. ${ }^{56}$ Over a century earlier, in 1318, the Latin cathedral of the town was mentioned in a will, followed by quite a few others who left money to the church, as well as requests of pious citizens to be buried there. ${ }^{57}$

Pilgrims' narratives very often mention the cathedral of Modon, but always in connection to the relics of St Leo and St Athanasius that were kept in it, thus neglecting to give a description of the building. The first mention of the church of St John in the travelogues dates back to 1469 , when an anonymous pilgrim

\footnotetext{
$51 \quad$ Kappas 2010, 244.

52 ' [...] à l'extrémité du bazar est une grande église à l'angle de laquelle un minaret indique qu'elle a servi de mosquée; son intérieur [...] est disposé comme les basiliques d'Italie, et divisé par deux rangées de colonnes en marbre, de dimensions et de nature diverses.' Blouet 1831, 11-12.

53 Tsougarakis and Lock 2014, 153; Hodgetts 1974, 39o-391; Panopoulou 1993, 289-290; Karydis 2010, 304; Kappas 2010, 197.

54 Kappas 2010, 244.

55 Anagnostakis 2o10a, 278; Follieri 1971, 386.

56 Follieri 1971, 386; Lampros 1926, 362; Lampros 1910, 156-157; Anagnostakis 2010a, 275-281.

57 Hodgetts 1974, 388 .
} 
attested celebrating mass along with his fellow travellers and seeing the precious relics held in Modon cathedral.58

References to the church of St John continue uninterrupted until 1500, when the town was occupied by the Ottomans, while some travellers mention it even after the occupation. The only pilgrim who provides information about the building is the Italian Pietro Casola in 1494: 'The town's cathedral, an episcopal church, could join the other miserable churches, sad and badly kept in every way. ${ }^{59}$ It could be assumed that the state of the church was not always the one described by Casola; what the pilgrim saw and reported could have been a result of the ongoing skirmishes with the Ottomans that led to the fall of Modon just six years after his visit.

As mentioned above, in 1500 the church was burnt during the invasion of the Ottomans and was later restored and turned into a mosque. ${ }^{60}$ As would be expected, after the occupation of Modon pilgrims' ships avoided stopping at its port, and references to the former Latin cathedral cease, with very few exceptions, mainly during the brief period of its second Venetian occupation (16861715). In 1825 the building was burnt once again during a battle between the Ottomans and the Greek rebels and was finally destroyed in the years following 1828, when the French troops under the command of General Nicolas-Joseph Maison used its remaining building material in the construction of a city outside the walls in an attempt to relocate the inhabitants of Modon. ${ }^{61}$

From the 1oth century the church of St John housed the head of St Athanasius, Bishop of Modon, and, from some point in the $15^{\text {th }}$ century onwards, the town's most venerated relic, the body of St Leo. All of the pilgrims referring to the church mention these relics, with a particular emphasis on the relic of St Leo, a 12th-century pilgrim saint, a saint with whom they shared the common experience of pilgrimage. ${ }^{62}$

$5^{8}$ 'Era il sabato infra la octava dil corpo de Christo e avegna già fosse cercha nona, però che giorni molti no avevamo celebrato, afamati et sitibondi de cosse spirituale, molti pelegrini volseno celebrare ne la eclexia catedrale di Modono. En la festa de Anastaxio, il quale fece il credo se canta ne la mesa e foy homo di quella cità. Ancora il corpo di uno beato Leone qualle continue fa de grandi miracoli.' Longo 2007, 154 .

59 'La sua giesia cathedrale, che è episcopale, pò stare de brigata con le altre: triste, molto male in ordine de ogni cosa.' Paoletti 2001, 144.

6o Follieri 1971, 380; Kappas 2010, 244.

61 Kappas 2010, 244, Follieri 1971, 382.

62 An analogous phenomenon can be seen in Cyprus, where the relic of St Jean de Montfort was worshipped. Jean de Montfort was a French noble and a crusader in the Holy Land, who died in 1248 in Cyprus. He was buried at the church of Beaulieu Abbey in Nicosia and was highly venerated by locals, as well as by foreign visitors. Many travelogues refer to his 
2.4.1 The Relic of St Leo

Modon's most venerated relic, the body of St Leo, appeared in the city in the 12th century. Information about its history is drawn from pilgrims' travelogues, as well as from two liturgical texts and a Synaxarion, dated to the 14th and $15^{\text {th }}$ centuries. ${ }^{63}$ According to these texts, Leo was a pious pilgrim who lived in the 12th century and died on the ship while either returning from or heading to the Holy Land.${ }^{64}$ His body, according to the Synaxarion, was buried at the seashore near Modon or, according to some pilgrims' narratives, thrown into the sea. ${ }^{65}$ St Leo then appeared in a dream of the Greek bishop of Modon, who retrieved his relic, which was indicated by the miraculous appearance of wisps in the sky, carried it and buried it in a place chosen by the saint himself. ${ }^{66}$ Later on, a church dedicated to his name was erected above his tomb. ${ }^{67}$ More details are given in the 14th-century Synaxarion, which clearly states the name of the

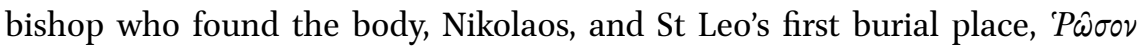
$X \hat{\omega} \mu \alpha$, as well as his birthplace, Calabria. ${ }^{68}$

In broad lines, combining the information concerning the saint's life, death and canonisation provided by the written sources, the legend of St Leo and the establishment of his cult in Modon can be summarised as follows: a man's body was found at the seashore near the town, probably in the first half of the 12th century. The body was retrieved at that time by Nikolaos (died $c$. 1165), Bishop of Modon, and was buried with all Christian honours, under the name Leo, on the hills outside the town, either in a pre-existing church or in a newly founded one. St Leo's relics were soon associated with miraculous healings and gained great fame. Following these events, Bishop Nikolaos composed hymns to the new saint and was the one who established and promoted the new cult. ${ }^{69}$

relic, which was preserved entire and was 'le plus beau mort qu'onques fut veu dessus la terre'; Nicholas le Huen (1487), Huen 1488, n.p. Pilgrims treated Jean de Montfort as one of their own, since they shared the experience of visiting the Holy Land, and the saint enjoyed much fame among religious travellers during the Middle Ages. About St Jean de Monfort, see Hackett 1901, 428-429; Delehaye 1907, 250-251; and the recent works of Michalis Olympios, Olympios 2012, 41-43; Olympios 2013, 334-340.

63 Follieri 1971, 402-403, 430-435; the aforementioned texts have been published by Enrica Follieri in Follieri 1971, 441-451.

64 According to the legend as conveyed by Nompar de Caumont, St Leo died 'au retour', while Antonio da Crema mentions that the saint died 'andando al sanctissimo loco di Terra Santa'. La Grange 1858, 90; Nori 1996, 140.

65 Follieri 1971, 404; Nompar de Caumont (1418-1419), La Grange 1858, 9o; Martin Ketzel (1476), Rhenanus 1832, 36 .

66 Follieri 1971, 405; Nompar de Caumont (1418-1419), La Grange 1858, 9 o.

67 Nompar de Caumont (1418-1419), La Grange 1858, 9 o.

68 Follieri 1971, 404-405. See also note 44 above.

69 Follieri 1971, 428; Steiris 2009-2010, 418-422. 
The first reference to St Leo's relic in pilgrim narratives is in 1384 by the Italian Simone Sigoli, and thereafter references to the miraculous relic continue uninterrupted until $1500 .{ }^{70}$ The French pilgrim Nompar de Caumont (1418-1419) shows great interest in the relic and conveys a detailed version of the saint-related legend, as well as important information concerning the first church that housed his body:

There, they told me that there was a church in which there was the body of St Leo, who during his lifetime was a shoemaker. [...] Near the town, they could not move forward, and they decided to place the body there and erect a church. As they say, he resides there since 80 years ago and performs great miracles by the grace of our Lord. When the town is at war, the inhabitants, knowing that misfortune will come and fearing to lose him, come to carry him inside the town. They do not take any action before moving him. I went to that church to see the saint's relic, which is kept by the Greeks behind the grand central altar of the church. I saw it in a closed case, entire, in way that would please him. ${ }^{71}$

So, according to the French traveller, St Leo's church was built in 1338, a year that does not correspond to the time of the retrieval of his relic, that is, in the

70 Lanza 199ob, 220.

71 The full text reads: 'Et là moy fut dit que à une mille et demye, en une églize anoye un corps saint, qui s'appelle saint Lion, qui fut sabatier au temps qu'il estoit en vie, et venoit du saint Sépulcre; et au retour, maledie luy pris en le nef de lequelle morut et fut geté en le mer dans une caisse; et la mer le alla porter à terre près de ledite cipté de Modon, et aucunes gens le trouvèrent, si se merveilloyent que c'estoit, et cogneirent que c'estoit ung home, et vont le enterrer en une fosse que ly firent; si que chacune nuyt, dessus ycelle foce où il estoit enterré, l'on veoit trois brandons de feu alumés par miracle de Dieu; et sy avint une nuyt eu à vizion al évesque de leditte cipté, que en ceul lieu avoye une corps saint et qu'il alasse par della, et le fit desenterrer et tenir en celle honneur, comme il apertenoyt d'un corps saint et qu'il estoit. Lors lendemeyn, quand ledit evesque fut levé, il révéla le chouse; et firent ordenance d'aller part della et menèrent évesques et plusieurs chapellens et autres gens ans grandes processions; et tantost là, où ils comensèrent et le mirent sur une charrue tiré aux buefs et ainsi le portérent. Et quant ilz furent prés le cipté, au lieu où à présent est, cuydant le porter dedens, ilz ne purent onquez passer plus avant, et convint que illéques le leissatent. Et fut là fette une église où ils demeure depuys ens se que l'on dit, a bien .lxxx. ans, et là fet de grans miracles par la vertz de Nostre Seigneur.

'Et quand il est temps de guerre en cell pays, ou ils ayent en la cipté ausqunes savance que malleur leur doye venir, pour dobtance de le perdre, ilz le vont querre et le porter en la cipté susditte. Mes se il n'est voir, ilz n'on puissance pour riens qu'ilz facent, de le movoir de son lieu. Et en ycelle églize je fuy pour veoir ledit corps saint, lequell tiennent les Grexs, au derrier le grant autel du cuer de leditte églize, en une caisse ferrée où je le vi tout entier, se luy plest.' La Grange 1858, 9o-91. See also the translation in Dansette $1997 \mathrm{~b}, 1101$. 
12th century. It could be suggested that the relic was found at a later period and that the identification of the town's bishop at the time with Nikolaos of Modon, who died around 1165, is erroneous. On the other hand, and given that the attribution of the saint's Synaxarion to Nikolaos can be sufficiently supported, it could be assumed that the holy relic was housed for some years in an already existing church until a church dedicated to his name was built. Nompar de Caumont mentions seeing the saint's body, at the time kept behind the altar of the choir, in a closed case, while he attests to the performance of a procession of the relic during troubled times, brought into the city in order to provide protection to the citizens, as well as to safeguard the relic from the enemy. As far as the saint's legend is concerned, it is of note that the usually very well-informed Felix Fabri, when referring to him near the end of the 15th century and probably influenced by the growing Ottoman threat, stated that St Leo was a German pilgrim killed by the Ottomans. ${ }^{72}$

There is no information provided in the Late Medieval travelogues or other sources about the reliquary, besides the aforementioned Nompar de Caumont and the Italian Pietro Casola. Both of them mentioned seeing the body of St Leo, entire, in a wooden chest. ${ }^{73}$ The lack of further descriptions allows the presumption that the saint's sarcophagus was not very elaborate, but it must have been adorned somehow, because Caumont mentions that the saint's body was kept 'in a way that would please him. ${ }^{74}$ The state of the reliquary when Casola saw and described it as a badly kept wooden case could be the result of neglect due to the Ottoman threat that was at its peak at the time of his visit.

What is important to note, since it seems to augment the significance of the relic, is the fact that it was preserved entire, thus worshippers could see and venerate the saint's whole body. Jean de Tournai, a Flemish merchant who visited Modon in 1488, attests to the fact that the body was exhibited entire: 'In this town, in the church of St John there is the body of St Lyon the confessor. The body is preserved entire. This saint died at Methoni, while returning from the Holy Voyage. The day I saw him he was wearing wooden shoes. ${ }^{75}$

72 ' $[.$.$] corpus S. Leonis, cujusdam peregrini teutonici. Poto autem illum fuisse peregrinum,$ qui inter Turcos mortuus non paucis claruit apud eos miraculis et postea ad Metonam per Christianos fuit translates.' Hassler, 1843-1849, vol. 3, 333.

73 Nompar de Caumont (1418-1419), see n. 71 above. In 1494 Pietro Casola reports that: 'dicto corpo m tenuto in una cassa de Ugno assai desutile'. Paoletti 2001, 145.

74 See $n .71$ above.

75 'Dans la ville, en l'église Saint-Jean est le corps de saint Lyon confesseur. Il y est tout entier; ce saint est mort à Méthoni en revenant du Saint Voyage. Le jour où je le vis, il avait aux pieds des souliers de bois.' Péricard-Méa and Blanchet-Broekaert 2012, 164. 
At some point, sometime around the end of the 15th century, the relic appears to be permanently housed in the cathedral of Modon, the Latin church of St John. ${ }^{76}$ There are no mentions in the texts about the place where the relic was kept in the town's cathedral. Given its popularity among locals, as well as pilgrims and visitors, it could be assumed that it was in a prominent location or at least easily accessible. After a certain point it must have been moved, probably for protection from the growing threat of the Ottomans. In 1494, only six years before Modon's occupation, the Italian pilgrim Pietro Casola mentions that in order to see the relics he and his fellow travellers had to ask the 'caretaker' to escort them. On top of that, again obviously because of the ongoing war with the Ottomans, the church appears to have been in a very bad state, while the saint's body was kept in a simple wooden case and was shown to them under very poor lighting. ${ }^{77}$

After the fall of Modon to the Ottomans in August 1500, a few mentions of the relic of St Leo indicate that his cult survived at least until the following century. Ottheinrich von der Pfalz, in 1521, states that the holy body was buried in the town, while Barthélemy de Salignac in $15^{22}$ and Denis Possot in $153^{2}$ mention that, 'Some say that the body of St Leo is in this town, while others say that he is still alive. ${ }^{78}$ Nevertheless, there are no traces of the relic after 1500 , and it is quite safe to assume that it was destroyed by the Ottomans along with the cathedral housing it.

Although there are no written testimonies, it can be deduced that the veneration of St Leo's relic would have been in keeping with Late Medieval practices: the pious would offer candles, make donations and, most importantly, touch the body, either with their clothes or with paternosters, in order to carry the saint's blessing with them. The surviving liturgical texts concerning St Leo also mention the popular notion that being close to or touching his reliquary could heal and bless the devout. ${ }^{79}$

The cult of St Leo emerged at a time when Modon was once again destroyed by enemy raids. Bishop Nikolaos himself, in 1147, after the attack of Roger II,

$76 \quad$ Follieri 1971, 399; Hodgetts 1974, 389.

77 'Alcuni de li peregrini feceno instantia per vedere le loro reliquie, dico de la giesia prenominata. Comenzando al custode che me pariva calzolaro, benché havesse una grande chierica, e poi el resto, me parse vedere una cosa molto trista. Tandem ne forono monstrate le reliquie con una lume ben trista.' Paoletti 2001, 144 .

78 Reichert 2005, 162. Barthélemy de Salignac (1522) and Denis Possot (1532), see n. 47 above.

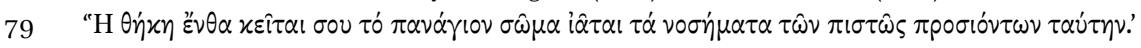
[The case where your holy body lies heals the maladies of those who come to you with

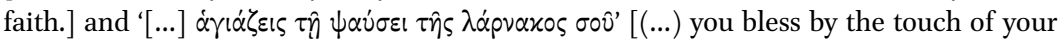
reliquary]. From the saint's exaposteliarion and canon, as published by Enrica Follieri in Follieri 1971, 427, 446. 
described Modon as an '[...] abandoned town, a town without citizens, walls and the security the walls provide..$^{80}$ So, the appearance of a miraculous relic that had the power to heal and protect the town was a much-needed morale and faith booster for the locals. At the same time, the legend that followed the new saint and, most importantly, his identification as a pilgrim made him extremely popular among the religious travellers who frequented Modon. Thus, St Leo's status both among the locals and the pilgrims comes as no surprise. For the inhabitants of the town, he was their protector, while for the pilgrims, the ones who circulated his fame to a much wider, international audience, St Leo was one of them. Who would be more appropriate to turn to during their journey than a man who shared their experience and attained saintliness? Last but not least, one should keep in mind the fact that Modon's St Leo was evoked in the Santa Parola, and, undeniably, this would have played a major role in the diffusion and elevation of the saint's cult. ${ }^{81}$

Therefore, the dissemination of St Leo's cult was to a great extent a result of his status as a pilgrim. The question that arises from this is: was the promotion of the worship of a Holy Land pilgrim organised and established with the aim of attracting religious travellers, or was it the pilgrims' desire that created and promoted this cult phenomenon? When the new saint was introduced to the inhabitants of Modon by their bishop in the 12th century, the fact that he was a pilgrim was to explain his appearance in the town rather than to attach importance to his relic. What Nikolaos of Modon needed at the time was a morale and faith booster for his flock, who had suffered a series of enemy raids. On the other hand, given the fact that since the Byzantine period Modon had been a stopping point for travellers to the Holy Land, a movement growing especially from the 13th century onwards, one cannot exclude the possibility that the promotion of the cult of a pilgrim saint aimed to attract a particular target group. ${ }^{82}$ Furthermore, given that the cult of St Leo was introduced in the 12th century and was quickly established in the area, it would be relatively safe to


2010, 410; Foutakis 2017, 98.

81 Bacci 2004b, 223-248, esp. 244.

82 During the entire period of its Byzantine history, Modon functioned as an important port of call on the marine route leading from the West to the Eastern Mediterranean, Constantinople and the Holy Land. It was during the Early Byzantine period that the town appeared for the first time as a stop for Christian pilgrims on their way to the Holy Land. In the autumn of 385 the Roman patrician Paula and her daughter Eustochia disembarked at the port of Modon, where they stayed for a few days to rest after sailing through the Adriatic. References to Modon as a port of call for pilgrims travelling to and from Jerusalem became more frequent in the following centuries, but it was after its occupation by the Venetians that the town was established as an important stop on the way from 
say that pilgrims were not the ones to create this cult. Nevertheless, they were undeniably the protagonists in its promotion, its wide diffusion and its elevation to an international pilgrimage by including the church housing the saint's body in their sacred topography of the sea route to Jerusalem.

\subsubsection{Liturgical Habits}

Given the popularity of the relic among pilgrims and travellers, as well as its importance for the inhabitants of Modon, and taking into consideration the religious practices of the period, it would be quite safe to presume that St Leo's body was carried in processions through the streets of the town on several occasions. Despite the fact that there is no evidence testifying to predetermined dates on which a procession involving Modon's most revered relic was held, one could assume that there would have been some sort of litany involving the relic at least on the saint's feast day, 12 May, as well as in times of peril. Furthermore, just like on Corfu, Crete and other Venetian-ruled Greek territories, Latins and Orthodox would participate in common liturgies and processions carried out during the most important religious feasts and they would most probably be related to the town's cathedral and its holy relics, which were commonly used by the government as agents to promote unity among the inhabitants of different rites. Nevertheless, sources of the period do not provide sufficient information, and there is no evidence attesting to the existence of such a rich spectrum of political and religious rituals as on the aforementioned islands.

However, pilgrims' travelogues indicate what could be considered as a common practice of the city's inhabitants, dating to at least as early as 1418: the procession of St Leo's relic in times of peril. As mentioned above, Nompar de Caumont (1418-1419) attests to the transportation of the relic inside the walled town when enemies approached..$^{83}$ It would be quite safe to assume that it was carried out in the form of a procession. Several years later, in 1470, the pilgrim Gaudenz von Kirchberg mentions a procession of St Leo's relic around the streets of Modon in order for the saint to protect them from an Ottoman attack. ${ }^{84}$ This testimony, especially when combined with Caumont's writings, indicates not only the importance of the relic for the town, but probably also

Venice to the Holy Land. Penna 2010, 32; Foutakis 2017, 95; Follieri 1971, 384; Avramea 1997, 43-44; Gertwagen 20oob, 147.

83 See $n .71$ above.

84 The full text reads: 'Es ist in derselben statt in den tumb ain heiliger genant Leon, den hat man ob dem auß der Morea von den Dürckhen hineingeflöcht und gepracht; denselbn heiligen trugen vier in ainer par mitsampt andern hailtumben am suntag in der pecesi in ale gass der stat zu Madon und volgten in proceß nach die herschafft und das volckh 
an established ritual. Even though no other sources corroborate this, pilgrims' testimonies undeniably reflect a common religious practice of carrying relics or miraculous icons in processions, attested since the Byzantine period.

At this point, it is worth mentioning that Modon, and most probably its cathedral, housed for quite a while, possibly during the 11th century, the relic of another St Leo: St Leo of Samos. Bishop of an unknown bishopric, he died on the island of Samos, and his relic, which was also considered to be miraculous, was transferred to Venice, stopping for a long period of time in Modon. ${ }^{85}$ This is why he was falsely identified as the bishop of Modon. This notion seems to have survived through time, as in 1481 the pilgrim Joos van Ghistele refers to St Leo as bisscops Leonis. ${ }^{86}$ So, Nikolaos, the Bishop of Modon, by introducing the cult of St Leo in the 12th century was offering the town another St Leo to replace the one that went to Venice. This could explain the attribution of the epithet véos (new) to the pilgrim saint in the Synaxarion composed by Nikolaos, the 'old' being St Leo of Samos, who was venerated in Modon for a long period of time. ${ }^{87}$

\subsubsection{The Relic of St Athanasius, Bishop of Modon}

Another holy relic that was venerated in the cathedral of St John was the head of St Athanasius, Bishop of Modon. The first mention of this relic was made by an anonymous pilgrim in 1469 , who wrote about 'Anastaxio, who composed the hymn chanted in mass and who was a man of this town'. ${ }^{88}$ Thereafter, references to it continue uninterrupted until the end of the 15th century. St Athanasius's relic appears to have been kept in the church of St John until the Ottoman occupation of the city in 150o. There is no specific information about the date when the head of St Athanasius was transferred to the cathedral of the town, but most probably this happened right after his canonisation in the gth century or the early 1oth.

According to his vita, St Athanasius lived in the gth century. He was born in Catania, Sicily, but fled with his family when he was ten years old to escape

von der stat und giengen die Krüechen am erstn in der proceßy; geschach wider die Dürckhen.' Röhricht 1905, 109 .

85 The relic of St Leo of Samos was later transferred to Zakynthos, from where it was moved to Malamocco in 1105 and later on to Venice, in 1109. It was initially kept in the monastery of San Servolo and, since 1615, in the church of Santa Maria dell'Umiltà, until its traces were lost. Bianco 1742, 186; Follieri 1971, 398; Steiris 20o9-2010, 422-423; Agathangelos, Maltezou and Morini 2005, 212.

86 Gaspar 1998, 61.

$87 \quad$ Follieri 1971, 398; Steiris 2009-2010, 422-423.

88 See $n .58$ above. 
the Arabs. He came to Patras in the Peloponnese, where he became a monk, a hermit and later on an abbot, until he was appointed bishop of Modon, an office he kept until his death, presumably around 880 . After his burial in the city of Modon, his grave became a source of miraculous healings and led to his canonisation and the translation of his holy relic to the town's cathedral. ${ }^{89}$ The only known written reference to St Athanasius of Modon is a funerary lamentation composed by St Peter of Argos in the gth century. ${ }^{90}$

Ever since the first mention of the relic of St Athanasius of Modon in the cathedral, there appears to be a misunderstanding about the identification of the bishop of Modon with St Athanasius, Bishop of Alexandria and alleged author of the then well-known Athanasian Creed, or Quicumque vult salvus esse. ${ }^{91}$ This attribution may have been an honest mistake because of the same names of the two bishops, but at the same time reflects the common phenomenon of the 'promotion' of a relic from an unknown or less important one to one of greater prestige. ${ }^{92}$

Other than that misunderstanding, there seems to be a huge confusion about the name of the person whose relic was venerated. Almost all of the pilgrims refer to him using a different name, in most cases a variation of the name Anastasius, while only four of the pilgrims use the name Athanasius, but attribute the relic to the bishop of Alexandria. ${ }^{93}$ One of these four, the Italian Antonio da Crema, conveys important information about the saintly relic: '[...] the head of St Atanasio, Bishop of Alexandria, which was found in a well and is at the cathedral church, with a golden circlet spliced at the forehead with these engraved letters: "Caput Anastasii alexandrini episcopi".94

According to the testimony of the Italian pilgrim, the saint's head was decorated with a golden circlet bearing an inscription identifying it as the

89 Follieri 1971, 401; Da Costa-Louillet 1961, 313-315.

$90 \quad$ Follieri 1971, 40O; Da Costa-Louillet 1961, 313-315; BHG, 72.

91 Waterland $1870,4-18$.

92 The case of St Athanasius of Modon is similar to the one of St Arsenius in Corfu, who was mistakenly identified as St Erasmus, much more familiar to a Western person; see p. 86 herein. In his travelogue of ${ }_{1527}$ Noè Bianco reported seeing St Athanasius of Alexandria's relics in the church of Santa Croce in Venice. Bianco 1742, 186.

93 The anonymous pilgrim of 1469 refers to an 'Anastaxio'. Longo 2007, 154. Most Frenchwriting travellers use the name 'Anastaise'. Schefer 189o, 47; Pinzuti and Tucoo-Chala 1972-1973, 121. Joos van Ghistele: 'Anastacius heleghen bisscop'. Gaspar 1998, 389. Felix Fabri: 'caput Anastasii, episcopi Alexandrini'. Hassler, 1843-1849, vol. 3, 333.

94 ' $[. .$.$] la testa di sancto Atanasio episcopo di Alexandria, quala fu ritrovata in uno pozo,$ qual è in lo corpo di la ecclesia catedrale, cum uno circhio di oro cinta e impiombata ne l'ossa di la fronte cum queste lettere intaglate: "Caput Anastasii alexandrini episcopi".' Nori 1996, 140. 
Alexandrian bishop. In addition, as transcribed by da Crema, the engraved name of the bishop is not Athanasius, but Anastasius. If such an inscription actually existed, it would explain the confusion of the pilgrims between the two names and the two saints and would allow the assumption that the relic of another bishop besides Athanasius of Modon was displayed in the town's cathedral. If, however, this was not the case, one could presume that, at least at the end of the 15th century, the aforementioned 'promotion' of a relic from an unknown or less important one to one of greater prestige was tolerated, if not actually orchestrated by the local religious authorities.

There are no mentions in the texts about the specific place where the relic was kept in the church of St John. As in the case of St Leo, the head of St Athanasius could be assumed to have been kept for a long period of time in a prominent or easily accessible location. The above-cited mention by Pietro Casola, that in order to see the relics they had to ask the 'caretaker' to escort them, may imply that this relic had also been moved in order to be protected from the growing Ottoman threat. ${ }^{95}$ There are no traces of St Athanasius's relic after the fall of Modon to the Ottomans in August 1500, and it is quite safe to assume that it was destroyed by the invaders, along with the cathedral.

At this point, it should be noted that the German pilgrim Felix Fabri, who visited Modon in 1480 and 1483 , mentions seeing in the cathedral of St John two fingers of Sts Cosmas and Damian. ${ }^{96} \mathrm{~A}$ few years later, in 1486 , the Italian pilgrim Antonio da Crema also refers to these relics. ${ }^{97}$ Fabri and da Crema are the only pilgrims to refer to Sts Cosmas and Damian's relics in the city of Modon, while there is no other evidence attesting to their presence in the cathedral. ${ }^{98}$

\footnotetext{
95 Paoletti 2001, 144-145.

96 Hassler 1843-1849, vol. 3, 333.

97 'Uno dido di sancto Cosma; uno dido di sancto Damiano'. Da Crema also mentions seeing the arm of St Martiniano in the church of St John: 'uno brazo di sancto Martiniano, qual fu d'i setantadui discipuli del nostro Signore messer Iesu Christo'. Nori 1996, 140.

98 Following the traces of the relics of Sts Cosmas and Damian (or Sts Anargyroi, as they are known in the Eastern ecclesiastical tradition), one comes across a long and not very clear history of alleged transfers, uncovering a dispute between Rome and Venice. According to the Perantiqua tabula romanae basilicae, in the frame of the sacra pignora movement, Pope Gregory I seems to have transferred the relics of Sts Cosmas and Damian to Bremen during the 1oth century, while in the 11th century their heads were placed by Henry II in the cathedral of Bamberg. On the other hand, according to Flaminio Cornaro and supported only by liturgical (the commemoration of the transfer celebrated on 10 May) or archaeological evidence (a graecanico opere elaborato reliquary), the relics seem to have arrived in Venice directly from the East in 1154. It is worth mentioning here that a number of Russian pilgrims report seeing the heads of the two saints, covered in gold, in Constantinople in a period spanning from the 14th to the 15th centuries. Van Esbroeck
} 
The value of information conveyed by pilgrims' narratives concerning the cathedral of Modon is of significant importance. They testify to its prominence among other religious institutions in the town throughout the 14th to the 16th centuries, due to its possession of the holy relic of the body of St Leo being well known among pilgrims. Reading carefully through the travelogues, the diffusion and significance of the now forgotten cult of St Leo becomes obvious, and, at least from the pilgrims' point of view, the cathedral housing his relic stood out as the most mention-worthy church and the major cultic focus of the town.

\subsection{The Franciscan Monastery}

The Franciscan monastery is the second most mentioned religious institution of Modon. It is not extant, and its presence is attested only by written sources, while no archaeological remains have survived to indicate its location. ${ }^{99}$

The Franciscans were active in the Peloponnese and had established a house in Coron already from the mid-13th century. ${ }^{100}$ The Franciscan monastery of Modon, on the other hand, seems to have been established in a later period, since it does not appear in the lists of Franciscan houses of the 14th century. ${ }^{101}$ It has been suggested that the founding of a monastery in Modon was already being planned in 1321, according to a decision of the Venetian Senate stating that the castellans of Modon and Coron had reached an agreement with the Franciscans of the province of Romania about the foundation of two new houses. ${ }^{102}$ In 1366, when Amadeus vI, Count of Savoy, visited Modon, the Franciscan monastery was already built. ${ }^{103}$ The next surviving mention of the monastery dates to 1446 , almost a century after the first one, when the pope confirmed Marcus of Modon as guardian of the monastery.104

Pilgrims' testimonies come to provide additional information about the Franciscans' presence in Modon, as well as to corroborate the fact that the monastery was active in the city until the end of the 15th century. Unfortunately, very few travelogues mention the Franciscan house of Modon, covering a narrow period of 16 years, between 1480 and 1496. Pierre Barbatre in 148o and Felix Fabri in 1483 both indicate that the Franciscan monastery was located

\footnotetext{
1981, 61-77; Agathangelos, Maltezou and Morini 2005, 91; Corner 1749, VIII, 128; Majeska $1984,45,151,163,333$.

99 Tsougarakis 2012, 137; Nanetti 2001, 348-349.

100 Nanetti 2001, 348-349; Hodgetts 1976, 390.

101 Moorman 1983, 306; Tsougarakis 2012, 137.

102 Tsougarakis 2012, 137.

103 Golubovich 1927, 120.

104 Tsougarakis 2012, 137.
} 
outside the city walls and that it was small and poor. ${ }^{105}$ Barbatre adds that at the time of his visit the Bishop of Modon was a Franciscan friar. ${ }^{106}$ In 1482 the Franciscan Conventual friar Paul Walther Guglingen visited the monastery and conveyed a graphic description:

In the same city, there are preachers and Minors, not reformed. The monastery of the Minors, the most miserable I have ever seen; they perform the divine office according to the Latins and the order of the Roman curia; [...] and I did not want to perform [mass] at the Minors due to the excessive misery, and there were no friars besides a young novice and a decrepit old man, who has scabies on the jaw, which has devoured his face up to the teeth. ${ }^{107}$

The Franciscan friar was obviously very disappointed by the monastery of Modon, which, at the time of his visit, was housing only two friars. Pietro Casola, the Italian pilgrim who visited Modon in 1494, shared the Franciscan's disappointment. ${ }^{108}$

In August 1500 the Ottomans occupied the town and that signalled the end of its Franciscan monastery. ${ }^{109}$ Just over 20 years after the city's fall to the Ottomans, in 1521 the German nobleman Ottheinrich von der Pfalz attested to the monastery's destruction by the invaders. ${ }^{110}$

In sum, very little is known about the Franciscan monastery of Modon. According to documents of the period, it seems that the Dominicans operated

105 Pierre Barbatre (1480): ‘[...] les Cordeliers sont hors la cité; toutes povres églises [...]'. Pinzuti and Tucoo-Chala 1972-1973, 122. Felix Fabri (1480, 1483-1484): 'Transivimus etiam extra urbem, ubi fratres Minores parvum conventum (habent) [...]. Hassler 1843-1849, vol. 3, 333-334.

106 ' [...] l'evesque est a Modon et est Cordelier.' Pinzuti and Tucoo-Chala 1972-1973, 122.

107 'In eadem civitate sunt Predicatores et Minores, heu non reformati. Monasterium Minorum miserabilius, quam unquam vidi; ipsi faciunt divinum officium secundum Latinos et ordinem curie romane; [...] et nolui dicere ad Minores propter nimiam miseriam, et non erant fratres dempto uno parvulo novitio et uno valde decrepito, qui habuit morpheam in maxillis, que devoravit faciem suam usque ad dentes.' Sollweck 1892, 81.

108 ' [...] benché in vero mon se li trovasse poi troppo concio de alogiamenti per peregrini, comenzando al Venerabile Patre chi usciti de galea, andando al convento de Santo Francesco; et io el sequitai, cedendo de megliorare conditione, ma li fu de fare asai.' Paoletti 2001, 143 .

109 Tsougarakis 2012, 137; Nanetti 2001, 349.

110 'Aber ein schone kirch Barfüsser ordens des rechten christlichen glaubens der heiligen christlichen kirchen zu Rom hat der Türk zerbrochen ein bolwerck oder mächtig vest darauf gemacht unndt die statt uffs aller vestes gebauwen.' Reichert 2005, 162. 
mainly in Modon and the Franciscans in Coron.111 The Franciscan monastery is sparsely mentioned in the travelogues. However, given the almost complete lack of information about it, the references to the monastery, albeit few in number, become valuable sources concerning the Franciscan presence in the town.

\subsection{The Dominican Monastery of St Mary}

The third Latin religious institution of Modon that was mentioned in the travelogues is the Dominican monastery of St Mary. The number and length of pilgrims' references to the Dominican monastery, in comparison to the ones concerning the cathedral of the town, are significantly smaller. Nevertheless, and given the fact that it is no longer extant and few documents regarding it have survived, the information provided by the pilgrims can be particularly useful in reconstructing a part of its history.

The Dominicans became active in Modon around the end of the 13th century, according to the oldest testimonies of the monasteries of the province of Greece in $1277 .{ }^{112}$ It has been suggested that the monastery of St Mary of Modon was founded after the permission given by the General Chapter of Trier in 1249 for the establishment of two new monasteries in the province. ${ }^{113} \mathrm{In}$ 1303 it appears for the first time in a listing of the order's establishments. ${ }^{114}$ In 1323 and 1327 the Commune made donations of grain and money to the monastery, while another decision of the same period, by which the friars were granted a quantity of wood for their construction work, testifies that they were either expanding or repairing their monastery. ${ }^{115}$ The church of the Dominican monastery, dedicated to St Mary, was a popular burial place for the locals. This church is referred to in two wills, dating to 1339 and 1358 , as ecclesia et conventus sancte Maria de ordine Fratrum Predicatorum, located within the walls of the town. ${ }^{116}$ By the 15th century it seems to have resolved its financial problems, since it appears to have been contributing to the expenses of the province in 1487 and $1491{ }^{117}$

111 Hodgetts 1974, 390.

112 Hodgetts 1976, 390; Nanetti 2001, 347; Tsougarakis 2012, 174. The Dominican Order's province of Greece was founded by the first General Chapter of the Dominicans, held in Paris in 1228. In fact, the General Chapter of the Dominicans, more than those of any other order, concerned themselves with the province of Greece. See Tsougarakis 2012, 169, nn. $1-2$.

113 Tsougarakis 2012, 174; Nanetti 2001, 348.

114 Nanetti 2001, 348.

115 Tsougarakis 2012, 174-175; Hodgetts 1976, 391.

116 Tsougarakis 2012, 174; Hodgetts 1976, 391; Nanetti 2001, 348.

117 Tsougarakis 2012, 175 . 
Ever since their settlement in Modon, the Dominican friars became a principle organ of charitable activities. They most probably organised and ran a hostel and a hospital in the city, since in 1323 they requested and received from the government a subsidy to cover the great expense of accommodating travellers. ${ }^{118}$

In August 1500 the Ottomans occupied the town and that marked the end of the monastery. ${ }^{119}$ No traces of it have survived, so its architecture, size and even its exact location in the town cannot be determined. What can be deduced from written testimonies is that the monastery was built inside the city walls and was a relatively small complex, obviously because of the constricted space in the walled part of Modon. ${ }^{120}$ As attested by two travellers who visited it in 1470 and 1474, the monastery suffered damage after an Ottoman attack before 1470.121

In 1384 the Florentine nobleman Lionardo Frescobaldi visited Modon and witnessed the burial of a priest fellow traveller at the church of the monastery: 'And here our priest from Casentino died, who, as we disembarked and put him on the ground, left this life [...] We buried him at the said castle in a church of the order of St Dominic which is there.'122

The German pilgrim Gaudenz von Kirchberg, who visited the monastery in 1470, provided some further information: according to his description, there were no more than four friars living at the monastery at the time of his visit, while its buildings were in a very bad condition due to an Ottoman attack. Other than that, which was commonly conveyed by most of the pilgrims, he refers to an 'icon of the Virgin holding the Christ Child painted by the Evangelist Luke, very beautiful to look at'.123 There is no other attestation to the existence of

\footnotetext{
118 Hodgetts 1976, 379-38o.

119 Tsougarakis 2012, 175; Nanetti 2001, 348.

120 Tsougarakis 2012, 174; Hodgetts 1976, 391; Nanetti 2001, 348. About the architecture of the churches of the mendicant orders, see Kitsiki-Panagopoulos 1979, 64-127.

121 Gaudenz von Kirchberg (1470) and Alessandro di Filippo Rinuccini (1474). Röhricht 1905, 109; Calami 1993, 53.

122 'E quivi morì il nostro prete di Casentino, il quale, come avemmo tratto di mare e posto in terra in sur uno stramazzo, passò di questa vita, che prima era stato parecchi dì quasi in fine di morte. Facemolo seppellire nel detto castello a una chiesa dell'ordine di san Domenico, la quale v'è.' Lanza 199oa, 174.

123 'Also fueren wier von der galee und gienngen in die stat, in sant Dominigencloster. Da pat wier herwerg, die uns durch die minickh vergunt wart. Und warn die zeitt nit mer dan vier minickh in dem closter, wenn die Tirkhen dem closter seine zinß, rent und nutz gantz genomen haben und verhört höten, daz sich dieselben minichen mit dem almuesen hörtigkhlichen betragen muesten. So kumbt es auch, das sich nit wol zwen minich in dem closter nören khinden. Und in demselben closter ist ain dafel, daran ist Unser Lieben
} 
such an icon in Modon; thus his mention, if one accepts its accuracy, becomes of significant importance.

In 1474 Alessandro di Filippo Rinuccini was even more descriptive: as stated by the Italian traveller, four years after Gaudenz von Kirchberg's visit, the monastery was still in a dilapidated state and facing obvious financial problems. In addition, it seems that the Ottoman threat was growing and that the friars had been preparing for a possible siege, since they had turned the second cloister into a cistern, while the refectory was used as a granary. ${ }^{124}$ After Rinuccini, five other pilgrims mention the Dominican house of Modon, in a period spanning from 1481 to 1495 .

The last mention of the monastery, by Wolfgang Zillenhart (1495) just five years before its probable destruction by the Ottomans, contains very important information in regard to the monastery's status in the town. The German traveller mentions that the Virgin was highly venerated by the friars in the monastery. He also refers to a procession that was carried out by the monastery's friars during an outbreak of the plague, when the Virgin saved the town. ${ }^{125}$ This information, while not clearly mentioning an icon, when combined with the testimony of Gaudenz von Kirchberg (1470) about a Lucan icon kept and venerated in the monastery could imply not only the icon's existence, but also its procession in the town and its fame among the inhabitants, since it was considered to have saved them from the plague.

Oddly enough, the Lucan icon mentioned by Gaudenz von Kirchberg does not appear in other travelogues or documents of the period. It could be assumed that the said icon was housed in the priory for a period of time, maybe on its way to Venice or another town of the West. On the other hand, his attestation could be indicative of the existence of a Marian cult in Modon that has been forgotten or overlooked since the priory's destruction.

Frawen pildnus gemald, das hat Unsers Herren pildnus in der schoß, die hat sant Lucaß gemald und ist aus der massen lieblich anzusehen.' Röhricht 1905, 109 .

124 '.... andai alla chiesa di Sancta Maria dove è il convento de'frati nostri, dai quali fui ricevuto con charità, secondo il modo de' conventuali et secondo la povertà del convento, il quale, oltre a non essere molto grande in circuito, anchora quello che è era assai impedito, imperoché dove già soleva essere il secondo chiostro de' frati, oggi discoperto tutto intorno s' è ridotto a essere citerna, la quale è murata in mezo et è molto grande et si tiene serrata a chiave pel comune per munitione a tempo di sospetto. Il refectorio è ridotto a essere granaio et ripieno di grano sta serrato con due chiavi di comune, riservandolo per munitione a tempo di sospetto.' Calamai 1993, 53.

$125[\ldots]$ das ander ligt in der statt, und ist brediger orden, haist zu unser frawen, und ist unser fraw gnedig da, wann sy hatt die statt ain mal von der pestilentz geledigget, gieng man mit ainer procession, da hort sy von stund auff, auch hett sy zecher auss den agen lasen fliessen, daß es ieder mann gesechen hett.' Gebele 1932-1933, 82 . 
The question that arises from the aforementioned is why would the existence of such an important effigy as a Lucan icon, mentioned in only one travelogue, not be propagated by such agents as the town's clergy or authorities? It could be suggested that Gaudenz von Kirchberg, as a pilgrim seeking objects or relics that could constitute a link with his final destination, Jerusalem, invested an icon with properties corresponding to his own desires or expectations. On the other hand, and given that so few documents concerning the Dominican monastery have survived, his attestation could be conveying a popular notion of the period that was forgotten through the course of time. Anyhow, Zillenhart's testimony a quarter of a century later seems to corroborate Gaudenz von Kirchberg's writings, although not directly mentioning a Lucan icon. Of course, this does not explain the silence of other pilgrims concerning it, but one should bear in mind the subjectivity of a narrative (the attribution of the famous icon of the Virgin Kassopitra to St Luke is also attested by only one pilgrim), as well as the fact that the town's cathedral kept and venerated the relic of a pilgrim saint, whose fame had surpassed its regional character and was included in the Santa Parola, thus attracting most of the pilgrims' attention. As far as the other agents who could have promoted the existence of a Marian effigy are concerned, neither was the cult of the town's most celebrated relic of St Leo promulgated by anyone other than the pilgrims. While this question remains to be answered, Gaudenz von Kirchberg's testimony could allow the insertion of the town's Dominican monastery into the network of Marian cult sites on the route to Jerusalem and at the same time points to the importance of pilgrims' narratives in raising aspects of religious life that would have otherwise gone unnoticed.

The amount and value of information conveyed by pilgrims' narratives concerning the Dominican monastery of Modon, despite the relatively small number and the limited length of their references to it, is of significant importance. They provide details about its buildings and the friars living in them in different periods and they attest to the fact that it was active in the city up until the end of the 15th century, while they constitute the only written testimony of the possible existence and veneration of a Lucan icon in the town.

Overall, Modon, as reflected in the travelogues, stands out as an important port of call on the sea route to the Holy Land, offering a safe harbour and amenities for the travellers, as well as markets both in the town and in the borgo, where traders and crew could carry out their commercial transactions. Nevertheless, and beyond the importance of the port for all those practical reasons, the 
town offered the religious travellers the opportunity to prostrate to and ask the protection of St Leo, a pious figure who, albeit unimportant in the saintly hierarchy, was closely connected to them through their shared experience of pilgrimage. So, despite the fact that it lacked impressive and elaborate churches and monasteries - a fact pointed out in many travelogues - Modon appears to have been fully integrated into the pilgrim's sacred topography as the town housing the body of a pilgrim saint.

St Leo's relic was obviously known to travellers from their marine experience, also being described in the Santa Parola litany, but, undeniably, the fame and extent of the diffusion of his cult among the religious travellers was due to their common experience, pilgrimage. It was the pilgrims who frequented Modon's port who propagated its fame and elevated it to an international level. As far as the other agents who could promote the cult and would benefit from its propagation, that is, the town's authorities, both religious and secular, they do not seem to have put much effort into it. In the end, Modon was in any case an important port, for commercial as well as strategic purposes, thus it was a stopping point for most of the ships travelling from the West to the East and vice versa. In a town that was under the constant threat of the Ottomans, retaining the port under their control, as well as not compromising the fragile social equilibrium, was vital for the local authorities, who appear to have remained orientated towards those goals. On the other hand, the saint's status as a pilgrim seems to have ascribed significant validity to his cult and seems to have been enough of a reason for it to be integrated into the pilgrims' itinerary to the Holy Land, rendering the town an important destination for religious travellers.

The case of Modon is indicative of the value of the information conveyed in pilgrims' narratives. If it had not been for the number of mentions to the saint's relic in the travelogues, the importance of the cult of St Leo would have not been perceived to its actual extent. The town's cathedral and the relic of St Leo could serve as an example of the way in which pilgrims actually contributed to the making of a sacred site by their persistence in visiting and referring to it continuously over two centuries, while their narratives, hundreds of years later, bring to light a long forgotten cult that was obviously very strong in its day. 